\title{
Peningkatan Hasil Belajar Materi Jaring-Jaring Bangun Ruang Melalui Penerapan Scientific Approach Siswa Kelas V SDN Grenden 01 Jember Tahun Ajaran 2015/2016 The Improvement Learning Outcomes Matter Web of Build Space Through Application of Scientific Appoach Student Class V of SDN Grenden 01 Jember School Year 2015/2016
}

\author{
Bella Ayunita Putri, Titik Sugiarti, Nanik Yuliati \\ Pendidikan Guru Sekolah Dasar, Fakultas Keguruan dan Ilmu Pendidikan, Universitas Jember (UNEJ) \\ Jln. Kalimantan 37, Jember 68121 \\ E-mail : titiksugiarti.fkip@unej.ac.id
}

\begin{abstract}
Abstrak
Proses pembelajaran terdapat beberapa persoalan yang berkembang terutama mengenai mencapai tujuan pembelajaran diantaranya yaitu ketika ada siswa yang mengerjakan soal di papan tulis, ditemukan beberapa kesalahan dalam proses pengerjaan dan jawaban akhir tersebut benar, siswa lain kurang cermat dalam mengamati hanya melihat hasil akhir. Pembelajaran juga masih terpusat pada guru sehingga berpengaruh pada proses hasil belajar siswa (nilai ulangan harian) masih rendah. Tempat dan waktu penelitian yaitu di SDN Grenden 1 Jember. Subjek penelitian adalah siswa kelas V SDN Grenden 1 Jember berjumlah 23 siswa. Jenis penelitian yang digunakan adalah penelitian tindakan kelas, satu siklus terdiri dari 4 tahapan, yaitu perencanaan, pelaksanaan, observasi, dan refleksi. Teknik pengumpulan data yaitu berupa observasi, wawancara, tes, dan dokumentasi. Proses analisis data penelitian ini menggunakan analisis deskriptif persentase, hasil belajar siswa. Hasil yang diperoleh dalam penelitian ini menunjukkan adanya peningkatan hasil belajar siswa. Rata-rata hasil belajar siswa secara klasikal pada prasiklus sebesar $58,26 \%$ yang termasuk kategori kurang baik, meningkat pada siklus 1 menjadi 68,96\% dengan kategori cukup. Siklus II juga mengalami peningkatan rata-rata hasil belajar secara klasikal menjadi 81,17\% dengan kategori sangat baik.Berdasarkan data tersebut dapat disimpulkan bahwa Scientific Approach dapat meningkatkan hasil belajar siswa materi Jaring-jaring Bangun Ruang kelas V SDN Grenden/1 Jember.
\end{abstract}

Kata Kunci: Hasil Belajar, Scientific Approach, Jaring-jaring Bangun Ruang.

\section{Abstract}

The learning process, there are several issues that developed, especially regarding the learning aims among others that when there are students who work on the problems on the board, discovered several errors in the process and the final answer is correct, the other students less careful in observing only see the end result. Learning is also centered on the teacher so influential in the process of student learning outcomes (test scores daily) are still low. The place and time of the study, namely in SDN Grenden 1 Jember. The subjects were students of class V SDN Grenden 1 Jember totaled 23 students. This type of research is classroom action research, one cycle consists of four phases, including planning, implementation, observation, and reflection. Namely data collection techniques such as observation, interviews, tests, and documentation. While the process of data analysis using descriptive analysis percentage, student learning outcomes. The results obtained in this study showed an increase in student learning outcomes. The average results of student learning classical at prasiklus amounted to $58.26 \%$, which includes the unfavorable category, increase in cycle 1 to $68.96 \%$ with the category enough. Cycle II also experienced an average increase in classical learning outcomes be $81.17 \%$ with a very baik. Berdasarkan categories of data it can be concluded that the Scientific Approach can improve student learning outcomes matter nets Build Classrooms SDN Grenden 1 Jember.

Keywords: Learning Outcomes, Scientific Approach, mesh nets geometry.

\section{Pendahuluan}

Menurut Depdiknas [2] Matematika sekolah merupakan pelajaran matematika yang diberikan di jenjang pendidikan menengah ke bawah. Matematika sekolah tersebut dipilih guna menumbuhkembangkan kemampuan-kemampuan dan membentuk pribadi serta berpandu pada perkembangan IPTEK. Oleh karenanya, matematika sekolah tetap memiliki ciri-ciri yang dimiliki matematika, yaitu memiliki objek kejadian yang abstrak dan berpola pikir deduktif konsisten Hal penting merupakan bagian dari tujuan pemeblajaran matematika yaitu meningkatkan hasil belajar. Menurut 
Susanto [5] yang dimaksud hasil belajar siswa adalah kemampuan yang diperoleh anak melalui kegiatan belajar. Untuk meningkatkan hasil belajar siswa, guru hendaknya memilih dan menggunakan strategi, pendekatan, metode atau teknik yang banyak melibatkan siswa aktif dalam pembelajaran, baik secara mental, fisik maupun sosial.

Pelaksanaan dalam proses pembelajaran matematika di sekolah SDN Grenden 01 Jember dirasa belum optimal. Dari hasil observasi tentang proses pembelajaran terdapat beberapa persoalan yang berkembang terutama mengenai mencapai tujuan pembelajaran diantaranya yaitu ketika ada siswa yang mengerjakan soal di papan tulis, ditemukan beberapa kesalahan dalam proses pengerjaan. Siswa lain kurang cermat dalam mengamati hanya melihat hasil akhir. Kesalahan yang sering dibuat siswa antara lain kurang tepat dalam membuat permisalan dan penyusunan operasi hitung matematika yang digunakan. Beberapa siswa sering bingung dalam menggunakan konsep yang telah mereka ketahui, misal saat siswa diminta mengerjakan soal mereka mengalami kesulitan. Hanya beberapa siswa yang sudah berani berpendapat yaitu mengajukan pertanyaan, selain itu beberapa jawaban siswa yang mempunyai langkah-langkah yang berbeda untuk soal yang sama akan tetapi masih banyak siswa yang tidak berani menunjukkan ide mereka dalam menyelesaikan soal tersebut. Pembelajaran juga masih berpusat pada guru, sehingga siswa hanya menjadi pendengar yang baik dan pengetahuan yang mereka dapatkan hanyalah pengetahuan yang ditransfer dari seorang guru sehingga konsep yang didapatkan bersifat hayalan saja bukan hasil dari pengalaman yang dimiliki para siswa itu sendiri.

Berbagai permasalahan yang terjadi pada siswa kelas V SDN Grenden 01 Jember, maka diperlukan suatu upaya yang efektif untuk mengatasinya. Salah satunya adalah mencari pendekatan pembelajaran yang kretif dan inovatif, yang bisa meningkatkan hasil belajar siswa dalam pembelajaran matematika sekaligus bisa membantu siswa melihat manfaat materi yang dipelajari dengan menghubungkannya dengan dunia nyata serta menerapkannya dalam kehidupan sehari-hari. Menurut Daryanto, [59-80] Salah satu pendekatan pembelajaran yang bisa menjadi alternatif adalah scientific approach (pendekatan ilmiah). Pembelajaran dengan scientific approach adalah proses pembelajaran yang dirancang sedemikian rupa agar peserta didik secara aktif mengonstruksi konsep, hukum atau prinsip melalui tahapantahapan mengamati (untuk mengidentifikasi atau menemukan masalah), merumuskan masalah, mengajukan atau merumuskan hipotesis, mengumpulkan data dengan berbagai teknik, menganalisis data, menarik kesimpulan dan mengkomunikasikan konsep, hukum atau prinsip yang "ditemukan". Berdasarkan latar belakang di atas, maka dapat dirumuskan masalah sebagai berikut. Bagaimanakah penerapan scientific approach dalam pembelajaran matematika materi jaring-jaring bangun ruang yang dapat meningkatkan hasil belajar siswa kelas V semester 2 di SDN Grenden 01 Jember tahun ajaran 2015/2016? Bagaimanakah peningkatan hasil belajar siswa kelas $\mathrm{V}$ dalam pembelajaran matematika materi jaring-jaring bangun ruang semester 2 melalui penerapan scientific approach di SDN Grenden 01 Jember tahun ajaran 2015/2016?

Tujuan penelitian ini adalah sebagai berikut.Untuk mendeskripsikan penerapan scientific approach dalam pembelajaran matematika materi jaring-jaring bangun ruang siswa kelas V semester 2 di SDN Grenden 01 Jember ajaran 2015/2016. Untuk meningkatkan hasil belajar siswa melalui penerapan Scientific Approach dalam pembelajaran Matematika materi jaring-jaring bangun ruang siswa kelas V semester 2 di SDN Grenden 01 Jember tahun ajaran 2015/2016.

Menurut Kustini $(2014,7)$ Matematika timbul karena pikiran manusia yang berhubungan dengan ide, proses, dan penalaran yang terbagi menjadi empat wawasan yang luas, yaitu aritmetika, aljabar, geometri dan analisis. Penerapan Scientific Approach dalam pembelajaran melibatkan keterampilan proses seperti mengamati, mengklasifikasi, mengukur, meramalkan, menjelaskan, dan menyimpulkan. Dalam melaksanakan proses-proses tersebut, bantuan guru diperlukan.

\section{Metode Penelitian}

Tempat penelitian di SDN Grenden 01 Jember semester genap tahun pelajaran 2015/2016. Subjek dalam penelitian ini adalah siswa kelas V SDN Grenden 01 Jember Kabupaten Jembertahun ajaran 2015/2016 dengan jumlah 23siswa yang terdiri dari 15 siswa laki-laki dan 8 siswa perempuan.

Penelitian ini menggunakan desain penelitian tindakan kelas (PTK). Teknik yang digunakan untuk mengumpulkan data dalam penelitian ini adalah: (1)Observasi; (2) wawancara; (3)Tes; (4) Dokumentasi. Menurut Masyhud [207] Data hasil tes dianalisis dengan menghitung hasil belajar Matematika setelah pendekatan Scientific dapat dilakukan

\section{dengan rumus:}

\section{$\mathrm{pi}=\frac{\Sigma s r t}{\Sigma s i}$ Keterangan:

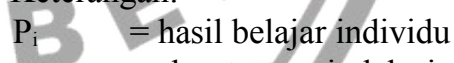 \\ srt = skor tercapai oleh siswa \\ si $\quad=$ skor ideal yang dapat dicapai oleh siswa}

\section{Hasil dan Pembahasan}

Berdasarkan hasil observasi, bahwa hasil belajar siswa mengalami peningkatan dibandingkan sebelum tindakan menggunakan Scientific Approach. Scientific Approach yang belum maksimal. Persentase hasil belajar siswa pada siklus 1, seperti gambar 1 berikut:

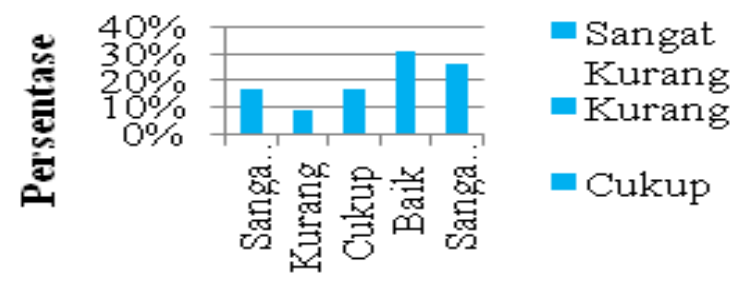

Gambar 1. Diagram Hasil Belajar Siswa Pada Siklus 1 
Gambar tersebut menunjukkan bahwa ketuntasan hasil belajar siswa sudah meningkat dan lebih baik dibanding hasil prasiklus yang sebelumnya. Berdasarkan hasil analisis hasil belajar siswa, diperoleh hasil persentase analisis hasil belajar siswa pada siklus 2, seperti pada Gambar 2 .

Berdasarkan Gambar 2, persentase hasil belajar matematika kelas $\mathrm{V}$ pada siklus 2 menunjukkan bahwa ketuntasan hasil belajar siswa sudah meningkat dan lebih baik dari siklus 1. Setelah dilakukan siklus 1 terjadi peningkatan skor hasil belajar siswa secara klasikal sebesar $68,96 \%$ yang termasuk kategori cukup. Skor hasil belajar siswa masih belum memuaskan, Maka dari itu, dilakukan siklus 2 untuk memperbaiki kekurangan yang terjadi pada siklus 1 agar semua siswa mendapatkan hasil sesuai dengan yang diharapkan. Pada siklus 2 skor hasil belajar siswa secara klasikal meningkat menjadi $81,17 \%$ yang termasuk dalam kategori sangat baik.

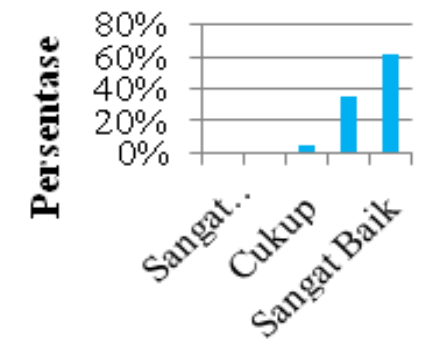

Gambar 2. Diagram Hasil Belajar Siswa Siklus 2

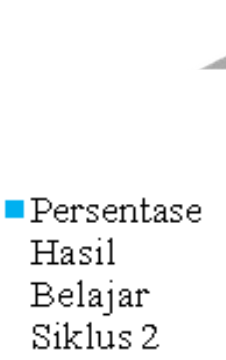

sulit dalam memahami permasalahan, membentuk kelompok yang dalam kelompoknya siswa terlihat belum terbiasa dengan situasi tersebut sehingga kelas menjadi ramai.

2. Penerapan pendekatan santifik (Scientific Approach) pada pembelajaran matematika pokok bahasan jaringjaring bangun ruang dapat meningkatkan hasil belajar siswa. Hal ini terbukti dengan adanya peningkatan hasil belajar siswa dari prasiklus ke siklus I hingga siklus II. Persentase hasil belajar siswa secara klasikal pada siklus I sebesar 68,96\% yang termasuk dalam kategori sangat baik, Persentase hasil belajar siswa semakin meningkat pada siklus 2 hasil belajar siswa secara klasikal sebesar $81,17 \%$ yang termasuk dalam kategori sangat baik.

Berdasarkan kesimpulan di atas, maka peneliti dapat memberikan saran sebagai berikut.

a. Bagi Guru

Pembelajaran dengan pendekatan saintifik (Scientific Approach) dapat dijadikan sebagai salah satu alternatif metode dalam pembelajaran matematika sebagai upaya untuk meningkatkan hasil belajar siswa;

b. Bagi Sekolah

Bagi lembaga pendidikan atau sekolah yang terkait, pendekatan sanintifik (Scientific Approach) dapat dijadikan salah referensi untuk sekolah dalam meningkatkan kualitas mengajar guru disekolah dan sebaiknya proses pembelajaran dikelaslebih diperhatikan dan media penunjang pembelajaran perlu disediakan agar dapat dipergunakan guru untuk meningkatkan mutu pendidikan;

Bagi Peneliti Lain

Bagi peneliti selanjutnya, perlu diadakan pengembangan Kesimpulan dan Saran

Berdasarkan hasil penelitian, analisis data, dan pembahasan dapat disimpulkan yang pertama yaitu :

1. Proses penerapan pendekatan saintifik (scientific approach) dalam pembelajaran matematika materi jaring-jaring bangun ruang pada siswa kelas V di SDN

1 Grenden Jember dilaksanakan sebanyak dua siklus, yaitu dengan siklus 1 dan siklus 2. Setiap siklus terdiri dari 2 pembelajaran dengan alokasi waktu $2 \times 35$ menit. Materi yang dibahas adalah kubus, balok, prisma segitiga, prisma segilima, kerucut, limas, tabung. Penerapan pendekatan santifik dalam pembelajaran matematika dilaksanakan dengan 5 langkah, yaitu: (1) menyampaikan kompetensi yang akan dicapai, (2) menyajikan materi, (3) memberikan kesempatan bertanya, (4) membentuk tim dengan anggota 3-4 siswa untuk mengerjakan lembar kerja kelompok, (4) mencari informasi, (5) mengolah informasi, (6) menarik kesimpulan, (7) mengkomunikasikan. Siswa terlihat lebih aktif dan senang selama pembelajaran Matematika menggunakan pembelajaran scientific approach. Keterbatasan pemahaman siswa terhadap materi jaringjaring bangun ruang telah teratasi karena dengan pembelajaran scientific approach ini ada proses pengolahan informasi yang melibatkan siswa secara berkelompok. Kendala yang dihadapi pada saat pembelajaran yaitu pada saat membiasakan siswa yang mengenai pendekatan sanintifik (Scientific Approach) agar tujuan pembelajaran dapat tercapai secara maksimal. Selain itu diharapkan dapat mengembangkan keterampilan mengajar dalam pengelolaan kelas upaya menarik minat siswa untuk belajar.

\section{Ucapan Terima Kasih}

Penulis mengucapkan terima kasih kepada dosen pembimbing tugas akhir yang telah membimbing selama penelitian.

\section{Daftar Pustaka}

[1] Daryanto, 2014. pendekatan pembelajaran saintifik kurikulum 201. Yogyakarta:Gaya Media

[2] Depdiknas, 2006. Standar isi KTSP. Jakarta:Badan Standar Nasional Pendidikan

[3] Kustini, Erni 2014. "Penerapan Model Pembelajaran Terpadu Berbasis Pendekatan Scinetific Untuk Meningkatkan Hasil Belajar IPA di Sekolah Dasar".(Skripsi).FKIP UNEJ

[4] Masyud, S. 2014. Metode Penelitian Pendidikan, Jember: Lembaga Pengembangan Manajemen dan Profesi Pendidikan

[5] Susanto, 2013. Teori Belajar dan Pembelajaran di Sekolah Dasar. Jakarta: Kencana 